\title{
The Second Global Bipolarity or Bi-Multipolarity
}

\author{
Rina Kirkova \\ Institute for Security, Defense and Peace Studies \\ rinakirkova@hotmail.com
}

\begin{abstract}
The purpose of this work is to identify the system of international relations that have taken place since Russia's role in international political relations got more influential. Many scholars argue in favor of multipolarity, others support the idea of alleged rebirth of bipolarity. There is also a group of scholars who seek arguments in favor of the concept of uni-multipolarity. The basic premise of this paper is that the analysis of the main features of the listed systems does not provide solid ground for understanding the current IR. Thus the paper is an effort in finding an answer about the concept and form of the current system of IR and its stability. It is done through analysis of the current system of international relations through the lenses of hybrid uni-multipolar system. Consequently, this paper is trying to propose a theoretical basis of a new hybrid system i.e. bimultipolarity as the best way in which the new international relationships could be understood and explained.
\end{abstract}

Key words: bipolarity, multipolarity, bi-multipolarity, systems of IR

\section{Introduction}

Scholars from all over the world have been debating and searching for answers about the system of international relations (IR) that follows the end of bipolarity. It seems that the vast majority of authors argue in favor of a raising multipolar world. Some scholars suggest that it is time to prepare for an universal world without dominations (Fukuyama), others were have been more realistic describing an unipolar world with only one superpower -the US (Huntington 1999). A group of scholars speak about variations of the already known systems of international relations, such as uni-multipolarity (Buzan and Weaver 2003). Despite the differences, in the focus of all debates is the quest for such a type of polarity 
that would be most peaceful, stable and durable. In this paper the first thesis is about the system of IR. The theoretical debate will be focused on the systems of IR and will give argument in favor of the bi-multipolarity, not only as a continuation of the post-Cold War period but also as a system that is stable.

The idea is not to analyze the entire post-Cold War period. The reason lies in the fact that during the first ten years (1990-1999), the US were victorious especially in ideological terms, and had predominant influence all over the world. That was the logical consequence after the end of bipolarity. The collapse of one element of the equation of the international balance meant end of bipolarity. The survivor was just one superpower and what followed was a wave of ideological domination, in terms of democratization and free market economy as expected and predictable. But since1999 when the international law was overtly breached in case of Kosovo, the US was no longer seen as redeemer or liberator of the world (Friedman 2013). That was the first turning point in the post-Cold war period that showed that universalism without domination of a hegemon was just a theoretical perspective with no sound empirical ground. The second period that had started with the NATO military intervention in the FR Yugoslavia over Kosovo ended in 2013. It was a period when most of the scholars from the field of IR started thinking about uni-multipolarisam (Nye, Buzan, Weaver). The current system was not stable. The lonely superpower (USA) took every chance or opportunity that arose to protect its interests. The military interventions in Afghanistan and then in Iraq proved that this was poor strategy of the US. They failed to impose a world order they desired, and the conclusion was that they were not as dominant as they thought they were.

The third (and current) period has begun with the end of the intervention in Libya which seems to have established a new structure of international relations. It was the first instance since the collapse of the bipolar system that Russia overtly opposed the US and its allies. It was clear that in any future case of breach of international law by the Western allies, especially if the Russian interests are affected, it will not pass as easy as the Libya intervention. This thesis was practically confirmed after the US unilateral action against the regime in Syria in September 2013. The US referred to the doctrine responsibility to protect in order to claim that in a case of humanitarian catastrophe the Security Council's permission is not necessary and also demonstrated its will to lead an operation for regime change in Syria. But this time Russia was resolute and did not remain a passive observer of the developments. Accompanied by China, Russia stood in defense of state sovereignty. Putin's statement was clear: military attack against Syria will be considered as military 
attack against Russia and China (Standford 2013). It was a clear demonstration of intention to protect not only sovereignty of Syria but also of the Westphalian foundations of the international order against the post-Westphalian ideas (such as responsibility to protect doctrine).

This event has become a significant turning point that indicated the end of the unipolar domination of the US. Hence on the international political arena two new great powers have raised. However it has not become quite clear if the unipolar system would be transformed into multipolarity or something else. Bipolarity assumes existence of two great powers that are prepared to compete over the leading role in international politics. Having three great powers on the top (USA, Russia and China) as well as several big powers inbetween (Germany, Britain and France) is a perfect explanation of multipolarity. And pessimists have seen a new multipolar world that would lead to the Third World War due to the lack of balance of power. Actually it is not the case. The polarity is not only a matter of distribution of power, but is also a matter of the interests of the states in power distribution (Kegley and Blanton 2012).

The Ukraine crisis shows that the biggest US concern is not China but Russia. The Ukrainian scenario was activated just couple of months after the failed campaign against Syrian regime. In addition to Ukraine and Syria (the two important geostrategic points for Russia) another issue has appeared in meantime - control of the Arctic. In every single politica Iconcern of the White House administration Russia was depicted as a violator of the international law and a potential enemy (Washington Times 16 Fevruary 2015). Between2013-2015 the US administration has strained its relations with Russia, and at the same time, it demanded from its partners to follow the US politics against Russia. One would notice they are policies that resemble the ones employed during the Cold War. Finally the two titans openly took the opposite sides at the UN General Assembly at the occasion of the 70th anniversary of the Organization (Putin 2015; Obama 2015).Apparently the world has got two old/new rivals; at the same time, the discussions about the world stability and the international system have got momentum.

Indeed, the features that may be used to describe the current structure of international relations fluctuate between multipolarity and bipolarity. However one must bear in mind that the ideal types of systems of distribution of power do not provide a comprehensive platform for analysis of the international relations after the rise of Russia. Although there are two major powers with tendency to compete for the leading role, there are still other important actors such as China, the EU member-states, India, Brazil, Iran and 
others smaller actors that show great interest in proactive participation in big games. Given this constellation, it is my belief that the most adequate description of the new structure of IR would be reflected via a model of a hybrid system of IR named bi-multipolarity.

\section{Understanding Bi-Multipolarity}

The post-Cold War international system has been explained from three standpoints. The first one is based on the idea of the new world order. According to this notion, power does not play significant role any longer, and while the role of state is declining, international organizations and economic corporations are gaining great significance in the international arena. These ideas could be found mostly in the works of neoliberals (Kegley 1993, Fukuyama 1992, Nye 1988). The second standpoint focuses on multipolarity. Supporters of this idea argue that since the Soviet collapse, Japan and the EU have become powerful actors in international affairs; furthermore, there are few other states that could be considered as big powers (Dowd 1992). Mearsheimer (2001) agrees with the thesis of raising multipolarity in the post-Cold War period, but he warned of its disastrous consequences for global peace. The third thesis has purported the idea of unipolarity in the post-Cold War period drawing conclusions on the ground of quantitative data. As the Soviet Union collapsed, there was only one superpower remaining - the US. Mathematically speaking, this would be a correct conclusion. But authors differ when it comes to the issue of the lasting of this system. Muravick (1991) and Vukadinovic (2004) identified Pax Americana, while others talk about American Hegemony (Layne and Benjamine 1993, 7). Yet Krauthammer (1990), in the article "Unipolar moment" exposes a vision of a short decade of American domination that would be transformed into unstable multipolar world.

However, all these discussions refer to the three core systems of IR systems. Besides that, a significant and vivid argumentation was going on in favor of a hybrid system called uni-multipolarizam. First theoretical explanation for this system is given in Samuel Huntington's paper "Lonely Superpower" (1999). His theses are very well advanced and convincingly supported by Jospeh Nye (2002) and Buzan and Weaver (2003). In this hybrid system, the US is considered superpower but there are also other big powers that are strong enough not to let the only superpower impose itself as hegemon. Thus, the unimultipolar system is a system with global domination of one super power that does not have corresponding global balancer; however, the power of the other regional hegemons can prevent the superpower from imposing its policies or interests on a global level. The regional centers of power are more than two, which gives the system a dimension of 
multipolarism. In such a system, balancing against the unipolar leader is possible, but it does not operate according to the rules of the game that apply when there are more than three big powers (Brooks and Wohlforth 2005). Balancing can be achieved through accelerated economic growth to support eventual rearmament (internal balancing) or by formation of international organization (external balancing), but there are no serious powers that can balance in every term of power (Cranmer 2005). Internal balancing is not a viable option against the unipolar leader because no increase in standing military forces or economic strength by just one state is adequate to the task. In the view of the external balancing, the other centers of power are not certain of the quantity of power that the others can pose and which of them would have the biggest potential to rise as second hegemon so they again fail to find solid foundation for cooperation in the joint attempt to balance the hegemony of the superpower (Pape 2005). Actually, there is one shared feeling of insecurity among the other regional powers, and this uncertainty makes them subalterns in relation to the only superpower. Therefore, they do not risk violating the relations with the only global power in order to establish global balance.

However, after the rise of Russia starting with the Georgia conflict form 2008 through the Syrian conflict in 2013, this thesis became not workable as it did not give ground for understanding the structure of the newly established international relations. In this new context, in addition to the US as superpower, Russia also has raised as a new power, independently opposing the superpower policy. Hence, the immediate question has been posed if this new situation could be interpreted as a bipolar system alike the one from the Cold War period (especially because the two main actors are the same) or maybe a new hybrid system of bi-multipolarism has been taking shape.

Looking into the logics of the uni-multipolarism hybrid, the bi-multipolarism would represent a system in which there are two big centers of power or two centers that are in open confrontation. Each party is aware that the other one is the key security problem for its national security. They carefully observe each other and their policy moves have direct impact on the global IR. The concentration of military, economic, technological domination and most recently - domination in media, is in the hands of the two rival powers; however, in this system, there are also other centers of power that could play crucial role in establishing balance of power or shaping the global IR. Unlike the pure bipolarity, in this hybrid system -even though the global policy is led by the two leading powers - the other centers of power are not firmly tied to either of the leaders and have freedom of choice on whether or not to follow them. Actually, their right to choose comes from their real power, 
expressed through all three components (economic, military, technological), their ideology (neoliberal capitalism vis a vi state capitalism), political system and the geostrategic position. These are the four main factors that influence the choice that regional centers of power would make in the bi-multipolar system. As in bipolarism, in bi-multipolarism there are alliances or blocks for establishing closer cooperation and partnership, but in bimultipolarism the membership in one organization does not exclude the freedom of choice in deciding to join an organization from the opposite flank. As in the bipolarism from the Cold War, in bi-multipolarism the proxy wars between the two powers are among the typical features; but in today's situation the other strong regional powers could play specific roles regardless whether it is all about following the policy of the leader from the own flank of about meeting one's own national interests. In certain instances, depending on their national interests, the regional powers can shift sides and support the superpower. In bimultipolarity balancing is all about equalizing the odds in a contest between the stronger and the weaker superpowers.

\section{Arguments in Favour of Bi-multipolarism}

Many eminent IR scholars cited above have made valuable theoretical contributions about the period of the US domination. However, the domination started to regress somewhat around 2008 with the global financial crisis (Nye 2010). The last instance of the US military domination was the regime change operation in Libya. This operations was led by NATO members France, Britain and Italy but gain huge support by US. Russia did not object the interpretation of the contested Resolution 1973 that was used as a legal ground on which the intervention was conducted and Gaddafi was toppled; however it did object firmly the US plan for military aggression of Syria and toppling the Basher al Assad regime. The moment Russia have stood in favor of Assad, the deeply altered constellation of the IR system has become obvious: the only superpower has got its rival in the face of Russia. One could guess that the 2014 Ukrainian conflict probably meant involvement of Russia in a direct military conflict with the Ukrainian forces or even with NATO, thus showing the world that the Putin's politic is not different than the SSSR politics from the time of the Cold War. But Putin managed to deter the anger of the international public very skillfully and succeeded to include Crimea without getting in to war with Ukraine or with the Western allies. Indeed economic sanctions were imposed but no one could afford a military confrontation with Russia. So what have actually changed so that today we speak about bimultipolarity? 
The two superpowers occupy the opposite sides of the earth (East and West). Those two nations have never been economically dependent on each other in any critical way. The US has no imports of goods from Russia that cannot be replaced from elsewhere. Russia, on the other hand is in somewhat more dependent position in terms of food and technologies, but it is not that crucial to put it in subordinate position. Therefore, Russia has not made itself dependant on the US. In the past several years Russia strengthened its relationships with the US potential partners and potential enemies, thus entering into economic war with US. Several grand projects related to the Euro-Asian region were developed with Russia acting as driving or uniting force in all of them. Such are the Eurasian Economic Union and the Shanghai Cooperation Organization where in addition to the member-states of the Organization for Cooperation and China, also India and Pakistan are included, while Iran, Afghanistan, Mongolia and Belarus have applied for membership. Russia has acted in capacity of uniting factor also during the establishment of the new financial structures of BRICS, which although not related to the Eurasian region still represents counterbalance to the Bretton Woods organizations where the US has the dominant role. In addition to the multilateral projects in which Russia has a leading role, shehas also joined several bilateral treaties with China, Iran and Turkey, primarily in the domain of trade and economic cooperation, but also on trading in domestic currencies. Each of the above Russian projects is aimed at weakening the US economy and the US petrodollar and to strengthen its own global position. The trade in domestic currency and the renouncing of the US petrodollar as international currency means launch of economic war from a point of view of the US. The Russian policy has also been followed by Iran that started selling oil for gold. Hence, the growth of the new block of states, linked to the Eurasian soil and the appearance of Russia as uniting factor of many regional powerful states, leads to the conclusion that the idea for Grand Europe in which Russia was supposed to be its eastern flank is falling apart and new project of Grand Eurasia, from Shanghai to Minsk, is taking shape, instead.

At the same time, the US has not remained indifferent to this economic war. Their friendly states from the OPEC countries have decreased the oil price in order to preserve the value of the dollar, and at the same time, to devastate the Russian economy that mostly profits on sales of energy sources. Additional hit Russia will probably face after the lift of the sanctions against Iran and the permission to export Iranian oil in Europe to follow, which will additionally impact the drop in oil prices.

Concurrently with the economic war, the two rival powers have launched serious media war. If only until recently Russia did not understand the meaning of the international 
public opinion and the propaganda war, launching of the Russia Today in English language means that Russia has decided to lead its own propaganda as opposed to the CNN and BBC propaganda. And, so far, it is succeeding. Mark Galeoty (2015) described the western concern with words "The west is getting too paranoid about Russia's information war".

The armament and technological war seem to be in the same rise they were during the Cold War. Both superpowers constantly increase the percentages within their budgets for the military industry and the new military technology. They constantly use the media support to promote their newest military-technological achievements. In the past years, Russia in continuity has increased the military budget and the projections for 2016 say it will reach around 98 billion dollars (RT 5 Feb. 2014; HIS 4 Feb, 2014), as opposed to the 585 billion dollars the US will allocate (Breaking Defense 11 April 2015; HIS 4 Feb. 2014).Although in terms of money the difference is huge, according to the US generals, the US is not in such a lead ahead of Russia to be able to defeat it militarily. However, both states remain the biggest nuclear powers. The arms race always leads inevitably to military conflicts. In this case, such two military clashes already take place on territories outside Russia and the US -such as Ukraine and Syria -under no justification, and with no UN consent. The proxy wars in which the two rivals are also the main actors is actually one of the main characteristics of bi-multipolarism. So far, in both cases, the US partners have defended the US policies and they act in opposition to Russia, while the Russian partners justify Russian policies. Along with Ukraine and Syria, the two rival powers have severely opposed geostrategic interests in relation to the Arctic, as well. The area concerned represents territory of around 1.2 million square meters with around 5 billion tons of gas. In addition to Russia and US, this territory is subject to interest of three other states Denmark, Norway and Canada which have opposed interests with Russia but, in this case, also with the US.

Hence, it is beyond any doubt that according to the dynamics and the activities undertaken by the two super powers, as well as the activities of the other great powers, a system is being developed which cannot be placed in the frames of any of the already theoretically explained three main systems and the hybrid called uni-multipolarism. It is rather a system that is hybrid and fluctuates between bipolar and multipolar. In other words, it is a system with two opposed super powers and several great powers that impact the formation of the IR. The policies and activities undertaken by the great powers can partially influence also the policies conducted by the two super powers, especially if in certain situations they refuse to follow the policy imposed by their leader - alternative, 
which in this system they can opt for. It is a possibility that leaves space for maneuver that makes this system more stable than the bipolar system that with the downfall of one super power leads to unipolarity; but also more stable than the pure multipolar world where general insecurity and ambiguity prevail in achieving the balance. In this bi-multipolar system the open animosity is concentrated between the two rival super powers. The great powers have the opportunity to balance in the moments when one of the two powers is ready to break the world peace or impose hegemonic policy.

\section{Conclusions}

The paper's aim has been to address the type of IR system with two dominant actors i.e. super powers that take active part in the creation of the global international relations, but in which along with them there are some other big actors, which even though without big global impact, do play significant role in shaping the international relations. From the presented argumentation, it can be concluded that since the main systems and the unipolarism as hybrid that were set so far, do not provide solid foundation to define it, the system in question is a new hybrid system of bi-multipolarism. The concept for bimultipolarism is only initially elaborated and set as topic for reflection and further development.

Concurrently setting the foundations of the hybrid bi-multipolarism opens the question also for its stability i.e. whether this system is more or less stable as compared to the basic systems of bipolarism and multipolarism. So far, it is too early to answer this question given the short time span since the appearance of this system. Analyses on the future of the strained relations mostly refer to the eventual fall of one of the poles, i.e. flanks. Some predict bankruptcy of the US and thus the beginning of the historical era of domination of the Eurasian actors, while others forecast financial collapse of Russia and the return of the US to the throne and re-establishment of the uni-multipolarism.

\section{References}

1. Brooks Stephen G. and William C. Wohlforth, International Relations Theory and Case against Unilateralism", September 2005, accessed September 2008 http://www.dartmouth.edu/ govt/docs/brooks\&wohlforth_perspective.pdf, , p.512

2. Buzan Barry and Weaver Ole, Regions and Powers: The Structure of International Security, Cambridge University Press, 2003 
3. Cranmer Skyler J., Ode to Unipolarity, 2005, Accessed 20 December 2014http://people.iq.harvard.edu/ scranmer/files/unipolarity.pdf

4. Galeotti Mark, "The west is getting too paranoid about Russia's information war", The Guardian, 07 July 2015, Accessed 30 September 2015,

http://www.theguardian.com/world/2015/jul/07/russia-propaganda-europeamerica

5. Friedman George,"Syria, America and Putin's Bluff", Geopolitical weekly, 10 September 2013, Accessed 20 november 2015, https://www.stratfor.com/ weekly/syria-america-and-putins-bluff

6. Hantington P. Samuel, "The Lonely Superpower", Foreign Affairs, March/April 1999, Accessed 15 September 2015,

https://www.foreignaffairs.com/articles/united-states/1999-03-01/lonelysuperpower

7. HIS report, Global Defence Budgets Overall to Rise for First Time in Five Years, 04 February 2014, accessed 30 September 2015 http://press.ihs.com/pressrelease/aerospace-defense-terrorism/global-defence-budgets-overall-rise-firsttime-five-years

8. Kegley Charls and Blanton Shannon, World Politics: Trend and Transformation, 2012 - 2013 edition, Cengage Learning Press, 2012

9. Krauthammer Charles, "Unipolar Moment", America and The World, Foreign Affairs 1990 issue, Accsesed 17 July 2015, https://www.foreignaffairs.com/articles /1991-02-01/unipolar-moment

10. Layne Christopher \& Schwartz Benjamin, "American Hegemony-Without an Enemy"Foreign Policy, \#92, fall 1993, 5-23 p, Accessed 10 September 2015, http://www.u.arizona.edu/ -volgy/LayneSchwarzAmericanHegemony.html

11. Mearsheimer J.John, The tragedy of Great Power Politics, NewYork: Norton, 2001

12. Nye Joseph, The paradox of the American Power: Why the world's superpower can't go it alone,0xford university press 2002

13. Nye Joseph, "The Future of American Power: Pominance and Decline in perspective", Foreign affairs November/December 2010, Accessed 10 September 2010, https://www.foreignaffairs.com/articles/2010-11-01/future-american-power

14. Obama Barak, obama address UNGA 28 September 2015, assessed 30 September 2015, https://www.youtube.com/watch?v=x6oxByE_IEU

15. Pape Nuechterlein Donald, Defiant Superpower, Potomac Books 2005 


\section{Securilatity}

16. Putin Vladimir, Address UNGA 28 September 2015, assessed 30 September 2015, https://www.youtube.com/watch?v=q13yzl6k6w0

17. Standford Daniel, "Russia's President Putin warns US over Syria action", BBC news, 04/09.2013, Accessed 20 November 2015,

http://www.bbc.com/news/world-europe-23955655

18. Vukadinovic Radovan, Medjunarodni politichki odnosi, Zagreb: Politicka kultura, 2004

19. Waltz Kenneth, "The stability of Bipolar World", International Political Analysis, Accessed 30 September 2015,

http://faculty.washington.edu/caporaso/courses/203/readings/waltz_Stabillity_0 f_a_Bipol.pdf 